\title{
THERMAL INSULATION WITH RECYCLED MATERIAL IN CREEPS FOR PIGLETS
}

\author{
Karina Sartor $^{1}$, Juliana de S. G. Barros ${ }^{2}$, Juliana Sarubbi ${ }^{3}$, Jonas B. Alonso ${ }^{4}$, Luiz A. Rossi ${ }^{2}$ \\ ${ }^{1 *}$ Corresponding authors. University of Campinas - UNICAMP - School of Agricultural Engineering, Campinas, Brazil. \\ E-mail: karinasartor78@gmail.com
}

\section{KEYWORDS}

piglets, thermal insulation, thermal efficiency.

\begin{abstract}
In the swine intensive farming, one of the biggest problems is to meet the thermal requirements of piglets in heated creeps, which demand high consumption of electricity and increase in production costs. The aim of this study was to evaluate the thermal efficiency and the consumption of electric energy in heated and internal insulated creeps, made of recycled material, when compared to creeps without thermal insulation. The treatments were: control (TCON): creep heated through suspended electric resistance, controlled by thermostat; thermal insulation with recycled material (TPK). The experiment was carried out for 21 days. In the treatments, the temperature $\left({ }^{\circ} \mathrm{C}\right)$ and relative humidity $(\mathrm{RH})$ of the air, consumption of electric energy (kWh), specific consumption $\left(\mathrm{kWh} \mathrm{kg}^{-1}\right)$, specific cost $\left(\mathrm{R} \$ \mathrm{~kg}^{-1}\right)$, weight gain $(\mathrm{kg})$ and daily weight gain $\left(\mathrm{kg} \mathrm{day}^{-1}\right)$ were measured. The indoor insulation creep kept the upper air temperature $\left(33.05^{\circ} \mathrm{C}\right)$ to the control treatment without thermal insulation $\left(32.6^{\circ} \mathrm{C}\right)$ and was more efficient in the use of electric energy $(2.46 \mathrm{kWh})$ in comparison to the non-insulated creep ( $3.48 \mathrm{kWh})$. The heat-insulated creep shelter consumed the equivalent of $1.02 \mathrm{kWh}$ more than the insulation treatment to maintain the thermal comfort condition of piglets between 30 and $34^{\circ} \mathrm{C}$. The conclusion is that the use of recycled material as thermal insulation in heated creeps reduces heat losses and economy electricity.
\end{abstract}

\section{INTRODUCTION}

In the swine maternity phase, one of the largest problems is meeting the calories demand of the newborn piglets with the use of heated creeps, which require greater consumption of electricity and increase in production costs. The monthly electricity consumption in swine's' farms in Brazil represents $4 \%$ of the total production cost (EMBRAPA, 2017). Therefore, alternatives of thermal insulation are sought for the facilities, in order to promote better thermal condition to the animals and to save electrical energy.

The newborn piglets have a poorly developed thermoregulation system which makes them sensitive to low temperature (Perdomo et al., 1987). Therefore, the newborn piglets should be kept inside the creep with air temperature between 30 and $34^{\circ} \mathrm{C}$ to avoid hypothermia (Vasdal et al., 2010). The use of heated creeps helps to maintain the homeothermia of piglets (Barros et al., 2010) and the maintenance of the temperature in the creeps depends on its ability to isolate and reduce heat losses.

The efficient use of electric energy in heated creeps depends on the thermal efficiency of the thermal insulation. Sabino et al. (2012) report that the temperature inside the creeps can be affected by the material used in the construction of the creeps and by the heat dissipation to the external environment. Fiorelli et al. (2009) used the material based on long-life packaging in zootechnical facilities and provided thermal comfort to the animals. Sartor et al. (2015) evidenced that the coating of creeps with long-life packaging exert the function of thermal insulation and provide better condition of thermal comfort to the piglets.

In this context, the use of recycled material, made with long-life packaging, is a viable alternative in the thermal insulation of creeps to promote the thermal comfort of the animals and to save electricity. Daré et al. (2005) show that the composition of the long-life packaging

${ }^{2}$ University of Campinas - UNICAMP - School of Agricultural Engineering/ Campinas - SP, Brazil.

${ }^{3}$ Federal University of Santa Maria (CESNORS/UFSM)/ Palmeira das Missões - RS, Brazil.

${ }^{4}$ University of Campinas - UNICAMP - Department of Statistics/ IMECC/ Campinas - SP, Brazil.

Received in: 8-5-2016

Accepted in: 9-18-2018 
(aluminum, cardboard and plastic) acts as a thermal insulation inside the installations.

The aim of this study was to evaluate the thermal efficiency and the consumption of electric energy in a heated creep, coated with a recycled thermal insulation board when compared to non-insulated heated creep.

\section{MATERIAL AND METHODS}

The experiment was carried out in the maternity ward at Granja Comercial de Suínos, located in the municipality of Capela do Alto, SP. The climate of the region, according to the classification of Köppen, is CfaSubtropical humid, with latitude $23^{\circ} 28^{\prime} 14^{\prime}$ ', longitude $47^{\circ}$ 44' 05 ' 'and altitude of $625 \mathrm{~m}$. The study period was from the piglets' birth to weaning, 21 days.

The creeps used were constructed in masonry with an area of $0.62 \mathrm{~m}^{2}$ and a volume of $0.46 \mathrm{~m}^{3}$. The creeps were internally coated with recycled thermal insulation (thickness of $1 \mathrm{~cm}$ ) and heated with an electric resistance of $250 \mathrm{~W}$ of nominal power and a digital thermostat that triggered the electrical resistances in the air temperature range of 30 to $34^{\circ} \mathrm{C}$ (Vasdal et al., 2010), considered the comfort zone for suckling piglets.

The digital thermostat used in the experiment was the N321 model, manufactured by NOVUS company. The temperature sensor used was a NTC thermistor (Negative Temperature Coefficient, with a measurement capacity of 50 to $120^{\circ} \mathrm{C}$ and a precision of $0.6^{\circ} \mathrm{C}$ ). The thermostat triggered the heating by controlling the actuator based on the internal temperature range of the creeps. This system features an on/off switching of the magnetic contactor, activating the resistors when the internal temperature of the room is below the lower temperature limit $\left(30^{\circ} \mathrm{C}\right)$ and turning off the resistors when the internal temperature reaches a value higher than the temperature limit $\left(34^{\circ} \mathrm{C}\right)$.

The insulation board is a commercial product made up of long-life packaging waste, subjected to the pressing process at a temperature of $180^{\circ} \mathrm{C}$. This material is composed of $70 \%$ cardboard, $20 \%$ plastic, $5 \%$ aluminum and $5 \%$ other recyclable wastes.

The thermal conduction coefficient $(k)$ of the insulation board is $0.01 \mathrm{~W} . \mathrm{m}^{-2}{ }^{\circ} \mathrm{C}^{-1}$ and was calculated based on the Energy Conservation Law (Incropera \& Dewitt, 1985). The thermal conductivity value characterizes the board as a material with low thermal conductivity (Baêta \& Souza, 2012).

In the experiment, twelve sows of the hybrid strain of Agroceres Pic were used and allocated in a maternity ward with their respective litter of piglets, totaling 140 piglets. The experimental design was completely randomized, consisting of two treatments, six replications (creeps) and their respective litters. The replicates were randomly distributed in the treatments.

The experiment consisted of the following treatments:
Control treatment (TCON) - Heating resistor with suspended electric resistance $(250 \mathrm{~W})$ and thermostat temperature control.

Treatment with thermal insulation (TPK) - Creep heated with suspended electric resistance $(250 \mathrm{~W})$, thermostat temperature control and internal insulation (recycled material).

The air temperature and relative air humidity were measured inside the creep and in the external environment using transmitters (RHT-WM model, NOVUS brand and accuracy $\pm 0.5^{\circ} \mathrm{C}$ ) connected to registers and accumulators of data (data recorded in intervals of 15 minutes).

The piglets were weighed individually at the beginning and end of the experiment (19 days) to calculate the daily weight gain (DWG), according to [eq. (1)]:

$$
\mathrm{DWG}=\frac{\mathrm{PWG}}{\mathrm{ND}}
$$

That:

$$
\begin{aligned}
& \mathrm{DWG}=\text { daily weight gain }(\mathrm{kg} / \text { day }) \\
& \mathrm{PWG}=\text { period weight gain }(\mathrm{kg}), \\
& \mathrm{ND}=\text { number of days the animals remain in the } \\
& \text { maternity ward. }
\end{aligned}
$$

The electrical energy consumption by the electrical resistances was measured by the Kron Mult-K Graphic with accuracy of current voltage, $0.2 \%$ power and $0.5 \%$ energy, of individual electronic energy with data storage (every 15 min).

The specific consumption ( $\mathrm{kWh} \mathrm{kg}^{-1}$ of live weight) was determined with the data of energy consumption $(\mathrm{kWh})$ between the treatments in relation to the product generated (daily weight gain), according to [eq. (2)].

$$
\operatorname{Csp}_{\mathrm{i}}=\frac{\mathrm{DCi}}{\mathrm{DWG}_{\mathrm{i}} \times \mathrm{N}}
$$

That:

$\mathrm{Csp}_{\mathrm{i}}=$ specific consumption of electric energy, ( $\mathrm{kWh} \mathrm{kg}^{-1}$ of live weight);

$\mathrm{DC}_{\mathrm{i}}=$ daily consumption of electricity, $\left(\mathrm{kWh}\right.$ day $\left.^{-1}\right)$;

$\mathrm{DWG}_{\mathrm{i}}=$ average daily weight gain, $\left(\mathrm{kg} \mathrm{animal}^{-1} \cdot\right.$ day $\left.^{-1}\right)$,

$\mathrm{N}=$ number of animals.

The specific cost $\left(\mathrm{Sc}_{\mathrm{i}}\right)$ was calculated with data of the specific consumption ( $\mathrm{kWh} \mathrm{kg}^{-1}$ of live weight) and of the electricity consumption tariff for the rural sector effective in 2014, according to [eq. (3)]:

$\mathrm{Sc}_{\mathrm{i}}=\mathrm{Csp}_{\mathrm{i}} \times \mathrm{T}$

That:

$$
\begin{aligned}
& \mathrm{Sc}_{\mathrm{i}}=\text { specific cost }\left(\mathrm{R} \$ \mathrm{~kg}^{-1}\right) \text { daily }(\mathrm{i}), \\
& \mathrm{T}=\text { energy consumption tariff }(\mathrm{R} \$ 0.22186130 \mathrm{kWh}) \\
& \text { for the rural area }(\mathrm{CPFL}) .
\end{aligned}
$$

The statistical analysis of the data was done by the Student $t$ test $(P<0.05)$ with the aid of the STATGRAPHICS plus software version 4.1. 


\section{RESULTS AND DISCUSSION}

The internal air temperature of the creeps differed $(\mathrm{P}$ $<0.05$ ) between treatments (Table 1). The TPK treatment temperature was higher $\left(33.05^{\circ} \mathrm{C}\right)$ numerically to the TCON treatment $\left(32.6^{\circ} \mathrm{C}\right)$, due to the thermal efficiency of the thermal insulation in reducing the heat losses from the internal environment of the creep to the external environment, along the time, as shown in Figure 1.The creeps coated with recycled material insulation (TPK) maintained the internal heat over longer periods of time (Figure 1) when compared to the non-heat insulated creep (TCON) that remained with the heating system on for a longer period of time to maintain the temperature of the air in the piglets thermal comfort zone, resulting in an increase of the electric power consumption (Figure 2).

In both treatments, the air temperature was maintained in the thermal comfort range $\left(30-34^{\circ} \mathrm{C}\right)$ for the piglets, according to reference values of Vasdal et al. (2010). The air temperature $\left(32.6{ }^{\circ} \mathrm{C}\right)$ in the TCON treatment was similar to that found by Pandorfi et al. (2005), in which heated creeps with electrical resistance provided average temperature values of $32.9^{\circ} \mathrm{C}$. Sartor et al. (2015) evidenced that the coating of creeps with only the reuse of long-life packaging improved the thermal comfort condition for piglets in heated creeps.
TABLE 1. Average values of air temperature, relative humidity in the treatments.

\begin{tabular}{lcc}
\hline Treatments & Air temperature $\left({ }^{\circ} \mathrm{C}\right)$ & Relative Humidity $(\%)$ \\
\hline TPK & $33.05( \pm 0.02) \mathrm{a}$ & $48.4( \pm 0.19) \mathrm{a}$ \\
TCON & $32.6( \pm 0.02) \mathrm{b}$ & $47.7( \pm 0.19) \mathrm{b}$ \\
Maternity ward & $23.0( \pm 0.04) \mathrm{c}$ & $55.8( \pm 0.04) \mathrm{c}$ \\
\hline
\end{tabular}

Average with different letters in the column differ from each other by Student's t-test $(\mathrm{P}<0.05)$.

The relative air humidity inside the creeps differed $(\mathrm{P}<0.05)$ among treatments (Table 1). In the TPK shelter, the relative humidity increased with increasing air temperature. Since the relative humidity of the air happens as a function of air temperature, the higher the air temperature is, the greater will be the air capacity to retain the water vapor, without affecting the thermoregulation and performance of the piglets (Barros et al., 2015). The relative air humidity did not reach the comfort range of $50-70 \%$, recommended by Miranda et al. (2012) in both treatments. According to Huynh et al. (2005), the daily weight gain of piglets is impaired when the combination of high temperature and high relative humidity occurs which was not observed in this experiment.

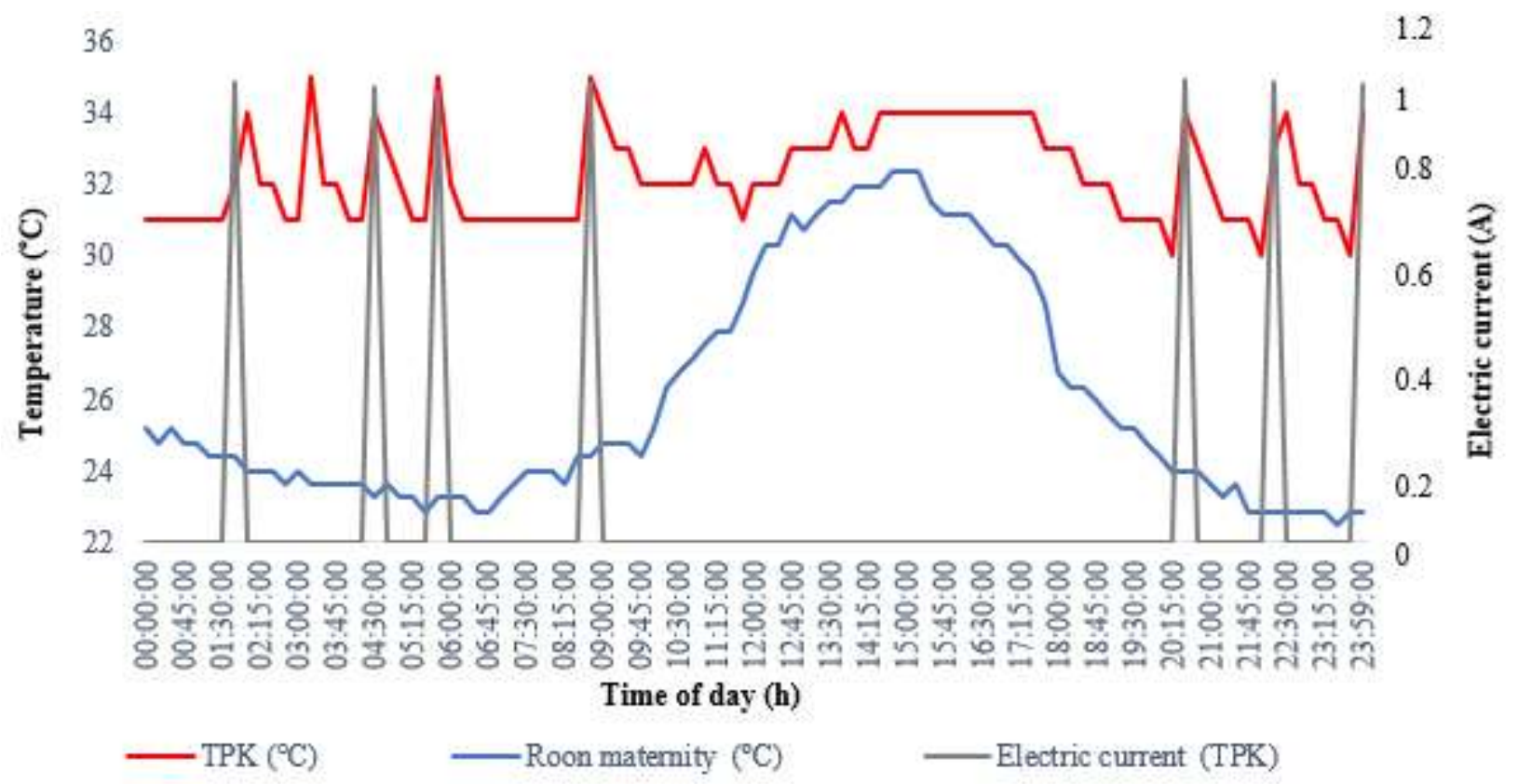

FIGURE 1. Illustration of the behavior of the internal air temperature $\left({ }^{\circ} \mathrm{C}\right)$ and electric current $(\mathrm{A})$ of the TPK shelter and maternity ward $\left({ }^{\circ} \mathrm{C}\right)$. 

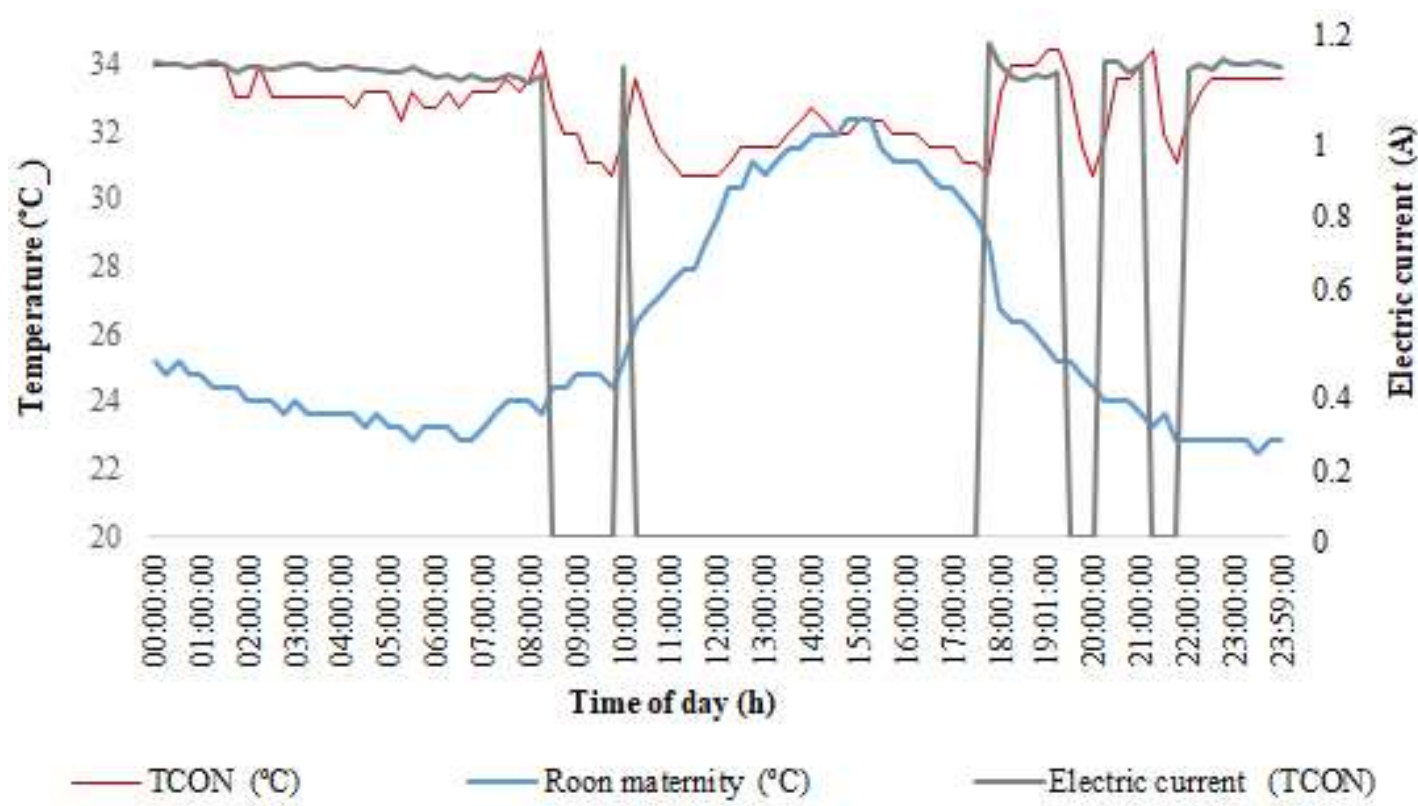

FIGURE 2. Illustration of the behavior of the internal air temperature $\left({ }^{\circ} \mathrm{C}\right)$ and electric current $(\mathrm{A})$ of the TCON shelter and maternity ward $\left({ }^{\circ} \mathrm{C}\right)$.

The piglets daily weight gain did not differ $(\mathrm{P}<0.05)$ between treatments (Table 2). The piglets submitted to the same thermal comfort temperature from 30 to $34^{\circ} \mathrm{C}$ showed the homogeneous weight gain, influenced by the same temperature variation. Ziron \& Hoy (2003) found similar daily weight gain, as they report that piglets gained daily weight gain of $0.221 \mathrm{~kg}$ in warm shelters with a temperature of $32.2^{\circ} \mathrm{C}$.

TABLE 2. Average daily weight gain $(\mathrm{kg})$ and weaning weight of the piglets $(\mathrm{kg})$.

\begin{tabular}{lcccc}
\hline Treatments & Initial weight & DWG $(\mathrm{kg})$ & Weight at weaning $(\mathrm{kg})$ & $\mathbf{N}^{\circ}$ piglets/litter \\
\hline TPK & $1.47( \pm 0.03)$ & $0.220( \pm 0.02)$ & $5.70( \pm 0.16)$ & $12.5( \pm 0.38)$ \\
TCON & $1.48( \pm 0.03)$ & $0.221( \pm 0.02)$ & $5.71( \pm 0.15)$ & $11.33( \pm 0.38)$ \\
\hline
\end{tabular}

The piglets weight at weaning did not differ (P $<0.05)$ between treatments. The piglets had weight at weaning of the approximately considered good (average weight of $6.63 \mathrm{~kg}$ ) by Fernandes et al. (2011). Jarvis et al. (2008) evaluated the effect of the piglets weaning age and found that piglets weaned at 21 days of age weighed about $6.10 \mathrm{~kg}$.
The average daily consumption of electrical energy (DCi) differed $(\mathrm{P}<0.05)$ between treatments (Table 3$)$. The use of the recycled material, based on long life packaging, as thermal insulation in the coating of the creep, reduced the daily consumption of electric energy by $1.02 \mathrm{kWh}$, except in the TPK treatment. This shows that the isolation of the creep has reduced the heat loss to the external environment and has triggered less the heating system.

TABLE 3. Daily consumption of electricity $\left(\mathrm{DC}_{\mathrm{i}}\right)$, specific consumption $\left(\mathrm{Csp}_{\mathrm{i}}\right)$ and specific cost $\left(\mathrm{Sc}_{\mathrm{i}}\right)$.

\begin{tabular}{|c|c|c|c|}
\hline Treatments & $\mathrm{DC}_{\mathrm{i}}\left(\mathrm{kWh}\right.$ day $\left.^{-1}\right)$ & $\mathrm{Csp}_{\mathrm{i}}\left(\mathrm{kWh} \mathrm{kg}^{-1}\right.$ of live weight $)$ & $\mathrm{Sc}_{\mathrm{i}}\left(\mathrm{R} \$ \mathrm{~kg}^{-1}\right.$ of live weight $)$ \\
\hline TPK & $2.46( \pm 0.26) \mathrm{b}$ & 0.16 & 0.03 \\
\hline TCON & $3.48( \pm 0.32) \mathrm{a}$ & 0.22 & 0.05 \\
\hline
\end{tabular}

Average with different letters in the column differ from each other by Student's t-test $(\mathrm{P}<0.05)$.

The electricity tariff of the farm used to calculate the specific cost was $\mathrm{R} \$ 0.22186130 \mathrm{kWh}$.

The specific consumption was $0.07 \mathrm{kWh}$ lower to produce $1 \mathrm{~kg}$ of live pig weight in the TPK treatment (Table 3) when compared to the TCON treatment. The specific cost in TPK was R\$ 0.16 lower compared to TCON. The specific cost represented $0.03 \mathrm{R} \$ \mathrm{~kg}^{-1}$ of live weight in the TPK treatment equivalent to $R \$$ $2,050.00 /$ litter and in the TCON treatment $\left(0.05 \mathrm{RS} \mathrm{kg}^{-1}\right.$ of live weight) $\mathrm{R} \$ 4,10.00 /$ litter. Since the use of thermal insulation with recycled material in creeps represents a saving of R \$ 2,060 in the cost of electric energy to produce $1 \mathrm{~kg}$ of live weight in a farm with 1000 sows.
The use of the ecological board as thermal insulation and temperature control was efficient, retained the internal heat in the heated creep, reduced the consumption of electricity and, therefore, resulted in the reduction of costs to produce $1 \mathrm{~kg}$ of live pig. In a similar study, the use of automatic temperature control in the heating system improves comfort conditions for animals and reduces the use of electric energy (Sarubbi et al., 2008). The efficient use of electricity is an important step in pig production, as it improves performance, welfare of pigs and reduces production costs (MacDonald, 2002). Thus, the use of the recycled board as a thermal insulation and temperature 
control thermally conditioned the heated creep shelters and reduced the consumption of electric energy. Besides the saving of electric energy in the heating of the creep, the use of recycled materials contributes to the preservation of the environment.

\section{CONCLUSIONS}

The use of thermal insulation board made from recycled material in creep shelters keeps the heat longer and reduces the consumption of electrical energy by heating sources.

\section{ACKNOWLEDGMENTS}

We would like to thank the ECOFUTURO company for the donation of the Tetra Pak ${ }^{\circledR}$ ecological boards and CAPES for the scholarship.

\section{REFERENCES}

Barros J de SG, Rossi LA, Sartor K (2015) Uso de controlador PID como tecnologia eficiente em sistema de aquecimento de creche suína. Revista Brasileira de Engenharia Agrícola e Ambiental 19(5):476-480. Available in: http://dx.doi.org/10.1590/18071929/agriambi.v19n5p476-480. Accessed: May 12, 2015.

Barros PC, Oliveira V, Chambó ED, Souza LC (2010) Aspectos práticos da termorregulação em suínos. Revista Eletrônica Nutritime 7(114):1250. Available in: http://www.nutritime.com.br/arquivos_internos/artigos/11 4V7N3P1248_1253MAI2010_.pdf. Accessed: May 11, 2015.

Baêta FC, Souza CF (2010) Ambiência em edificações rurais: conforto animal. Viçosa, UFV, 2ed. p88.

Daré CAN, Targa LA, Isa MM (2005) Avaliação da eficiência de isolantes térmicos por reflexão, utilizados como subcoberturas. Engenharia Agrícola 20(2):14-20. Available in: http://200.145.140.50/html/CD REVISTA ENERGIA vo 12/vol20n22005/Artigos/Carlos $\% 20$ Alberto $\% 20$ Neme $\% 20$ Dare.pdf. Accessed: May 12, 2015.

Fernandes HC, Morreira RF, Longui FC, Rinaldi PC, Siqueira WC (2011) Efeito do aquecimento e resfriamento de pisos no desempenho de matrizes e leitões. Revista Ceres 58(6):701-709. Available in:

http://www.scielo.br/scielo.php?pid=S0034737X20110006 00004\&script=sci_arttext. Accessed: May 12, 2015.

Fiorelli J, Morceli JAB, Vaz R, Dias A (2009) Avaliação de eficiência térmica de telha reciclada à base de embalagens longa vida. Revista Brasileira de Engenharia Agrícola e Ambiental 13(2)204-209. Available in: http://www.scielo.br/pdf/rbeaa/v13n2/v13n02a15.pdf. Accessed: May 12, 2015.

Huynh TTT, Aarnink AJA, Verstegen MWA, Gerrits WJJ, Heetkamp BK, Canh TT (2005) Effects of increasing temperatures on physiological changes in pigs at different relative humidities. Journal of Animal Science 83:13851396. Available in:

https://dl.sciencesocieties.org/publications/jas/pdfs/83/6/08 31385. Accessed: May 11, 2015.

Incropera FP, Dewitt DP (1985) Fundamentals of heat and mass transfer. Toronto, Jonh Wiley \& Sons, 2ed, p802.
Jarvis S, Moinard C, Robson SK, Summer EH, Douglas AJ, Seckl JR, Russel AJ, Lawrence AB (2008) Effects of weaning age on the behavioural and neuroendocrine development of piglets. Applied Animal Behaviour Science 110:166-118.

MacDonald R (2002) Saving Money by Maximizing Energy Use Efficiency in Swine Production. Advances in Pork Production 3:99. Available in: http://www.prairieswine.com/pdf/2371.pdf. Accessed: May 11, 2015.

Sartor K, Sarubbi J, Lazzari R, Souza S, Paim RW, Medeiros BBL (2015) Utilização de embalagens Tetra Pak ${ }^{\circledR}$ como isolante térmico no revestimento de escamoteadores para leitões. Arquivo Brasileiro de Medicina Veterinária e Zootecnia 67:1449-1456.

Sabino LA, Paulo Giovanni de Abreu PGA, Sousa Júnior VR, Abreu VMN, Letícia Lopes LS (2012) Comparação de dois modelos de escamoteadores sobre o desempenho dos leitões. Acta Scientiarum. Animal Sciences 34(1):2125. Available in:

http://periodicos.uem.br/ojs/index.php/ActaSciAnimSci/art icle/view/11675/pdf. Accessed: May 13, 2015. DOI: http://dx.doi.org/10.4025/actascianimsci.v34i1.11675

Sarubbi J, Rossi LA, Larangeira EG, Oliveira RA, Velloso NM (2008) Uso racional de energia elétrica e conforto térmico em instalações para suínos em crescimento e terminação. Revista Brasileira de Engenharia de Biossistemas 2(2):185-192. Available in: http://seer.tupa.unesp.br/index.php/BIOENG/article/view/7 2/72. Accessed: May 11, 2015.

Miranda SKO, Borges G, Menegale VLC, Silva IJO (2012) Efeito das condições ambientais no nível de ruído emitido por leitões. Engenharia Agrícola 32(3):435-445. Available in: http://www.scielo.br/pdf/eagri/v32n3/03.pdf. Accessed: May 11, 2015.

Pandorfi H, Silva IJ, Moura DJ, Sevegnani KB (2005) Microclima de abrigos escamoteadores para leitões submetidos a diferentes sistemas de aquecimento no período de inverno. Revista Brasileira de Engenharia Agrícola e Ambiental 9(1):99-106. Available in: http://www.scielo.br/scielo.php?script=sci_arttext\&pid=S1 41543662005000100015. Accessed: May 11, 2015.

Perdomo CC, Sobestiansky J, Oliveira PAV (1987). Efeito de diferentes sistemas de aquecimento no desempenho de leitões. Concórdia: EMBRAPA CNPSA. Comunicado Técnico, 122, 1.

Vasdal G, Graerum M, Melisova M, Knut EB, Donald MB, Andersen IL (2010) Increasing the piglets' use of the creep area-A battle against biology? Applied Animal Behaviour Science 125:96-102. Available in: http://www.sciencedirect.com/science/article/pii/S0168159 110001310\#. Accessed: May 11, 2015. DOI: http://dx.doi.org/10.1016/j.applanim.2010.04.010

Ziron M, Hoy ST (2003) Effect of a warm and flexible piglet nest heating system-the warm water bed-on piglet behaviour, live weight management and skin lesions. Applied Animal Behaviour Science 80:9-18. Available in: http://www.sciencedirect.com/science/article/pii/S0168159 10200206X. Accessed: May 11, 2015. 